undermined; the surface had a glazed appearance, and secreted a very little watery discharge; its base was surrounded by slightly indurated tissue, which was somewhat inflamed. At the angle of the jaw on the same side was an enlarged gland, not inflamed, about the size of a bean. As the situation of the ulcer corresponded with the position of the chain of the man's helmet, it was thought probable that either the metal of the helmet chain or some substance used in cleaning it had irritated an abrasion on the cheek and so caused the ulcer. The man had no constitutional symptoms. The ulcer was considered to be a poisoned wound, and treated accordingly, first with poultices and hot fomentations, then, when the inflammation had subsided, with diluted red oxide of mercury ointment. In less than three weeks it had quite healed; the slight amount of induration at its base had disappeared; the gland, however, remaining as before, and showing no signs of inflammation. The man was about to be discharged from hospital, and was being examined as to his general condition for this purpose, when a copious rash was seen on his chest, back, and abdomen, extending also to the arms. The rash was mainly papular, but squamous and roseolar in places, and markedly polymorphic ; in appearance and colour it was undoubtedly a secondary syphilitic eruption. There was no previous history of syphilis, or any appearance or traces of a sore in the usual situations, and the man stated that he had never had one. The patient was kept in hospital and treated with perchloride of mercury and small doses of iodide of potassium, and by Jan. 20th the rash and the enlarged gland were nearly gone.

The interesting points of this case are-(1) the very unusual situation of the infecting sore; and (2) the early appearance of secondary symptoms, which is probably accounted for by the very free blood-supply to the part. The sore was probably caused by an abrasion on the cheek becoming accidentally poisoned by syphilitic virus.

Portland.

\section{ON THE INFLUENCE OF SALICYLIC ACID UPON ACUTE RHEUMATISM.}

BY T. F. Raven, I.R.C.P. LoND.

IN the treatment of acute rheumatism with salicylate of soda or potass very different results are obtained. Sometimes the remedy acts in a wonderfully satisfactory way, and in a few hours the patient is free from pain, and in a few days convalescent. At other times, but fortunately less frequently, the drug produces no beneficial effect whatever. Until lately I have been at a loss to distinguish the cases amenable to treatment with salicylic acid from those which gire no results, but a recent experience has given me a clue which may possibly be of some value. During the prevalence of an epidemic of membranous tonsillitis in an institution, three severe cases of acute rheumatism, with cardiac complications, presented themselves, certainly resulting from the prevalent poison. In the treatment of these cases salicylate of soda entirely failed either to reduce temperature, to relieve pain, or to arrest the disease. I was so struck with the failure of the drug in three successive cases that the possibility occurred to me of explaining it by the origin of the disease. It may be that the acute rheumatism which results from zymotic influences is different in its nature, though not apparently in its symptoms, from that which arises from cold and damp.

Broadstairs.

\section{A N ENORMOUS C $A$ L CULUS. \\ Br E. Corson, M.R.C.S., SURGEON-MAJOR.}

JABTER NASSIR, a Bedouin Arab who had come eight days' journey to Hodeedab, and thence by sea to Aden, presented himself at the Civil Hospital for treatment for calculus of the bladder. On Feb. 1st, when on the operating table, the stone was carefully examined with the sound and per rectum. Having come to the conclusion that the stone was a very large one, I determined on the supra-pubic operation. The bladder was injected with twenty ounces of warm water, which raised it well above the pubes. An incision about three inches in length was made vertically above the pubes, and the parts carefully dissected down until the veins above the bladder were exposed. Whilst separating these with a director, it passed through into the bladder, which appeared soft and friable. The finger was immediately introduced through the opening, and an enormous stone was found to occupy the cavity of the organ. To extract this the original incision had to be much enlarged, and with great difficulty the stone was removed. This was found to weigh $9 \frac{1}{2} \mathrm{oz}$. avoirdupois, and measured $7 \frac{1}{2} \mathrm{in}$. in its horizontal and $8 \frac{1}{2}$ in. in its vertical circumference. A large catheter was fastened in the bladder per urethram, and the wound in the skin closed and dressed antiseptically. The man recovered well from the immediate effects of the operation, and was doing well also in the evening. I regret to say he died suddenly on the following morning. No post-mortem examination was made, as the Arabs object to such a measure. The distension of the bladder alone appeared to answer every purpose, as the peritoneum was not seen from first to last. The man said he had had the stone for ten years, but as he would be entirely ignorant of means of computing time, such a history is quite untrustworthy. Aden.

\section{d attiruror}

\section{OF \\ HOSPITAL PRACTICE, BRITISH AND FOREIGN.}

Nulla autem est alia pro certo noscendi via, nisi quamplurimas et morborum et dissectionum historias, tum aliorum tum proprias collectas habere, et inter se comparare.-Morgagni De Sed. et Caus. Morb., lib. iv. Procmium.

\section{ST. BARTHOLOMEW'S HOSPITAL.}

SARCOYA OF THE TONGUE; REMTOVAL OF HALF OF TONGUE RECOVERY; REMARKS.

(Under the care of Mr. ButLIN.)

ConNECTIVE-TISSUE tumours of the tongue are so very rare that the account of the following growth will be read with great interest. Appended to the remarks will be found references to other tumours of this part, and the list is not a large one. The diagnosis has to be made from gumma, and in order to do this it is necessary to give large and increasing doses of the iodide of potassium. This treatment was fully tried in this case, and the swelling punctured, without improvement. For the following notes we are indebted to Mr. Knight.

C. J-a a a f forty, car-driver, was admitted into Rahere ward, Oct. 12th, 1886, with a swelling of the left half of the tongue. The patient first noticed a soreness about the middle of the left side of the tongue two months ago, and a swelling at the same spot one month ago. The swelling had increased rapidly. He had had no pain except on eating; he never had syphilis; he had smoked cigars, but never a pipe. Always enjoyed good health. Family history good.

On admission he was a healthy-looking, strong man. Situated in the substance of the lett half of the tongue was a smooth, soft, elastic swelling, bulging on the upper and under surface of the tongue, and about the size of a fives ball. It did not extend across the middle line, but reached. from the junction of the anterior and middle thirds to the back of the tongue. The latter could not be protruded from the mouth. There was no ulceration. A hard and enlarged gland was felt beneath the jaw in the submaxillary region. The teeth in the upper jaw were mostly in a decayed condition. Under the impression that the tumour contained fluid it was punctured five days previously, but only blood exuded. He was ordered ten grains of iodide of potassium three times a day.

Oct. 16th.- Fifteen grains of the iodide were ordered. No change in swelling.

19th.--Iodide increased to twenty grains. Tongue can be protruded a little further.

$22 n d$-Twenty-five grains of the iodide to be taken. No further change.

23rd.-The under surface of the tongue was painted with a 4 per cent. solution of cocaine and the swelling again punctured. $A$ few drops of blood only exuded.

25 th. - Thirty grains of iodide of potassium ordered. 